\title{
Les cycles de la conception : les techniques de normalisation dans un centre de traitement de la stérilité
}

\section{Charis Cussins}

\author{
(2) OpenEdition \\ Journals \\ Édition électronique \\ URL : https://journals.openedition.org/tc/523 \\ DOI : $10.4000 /$ tc. 523 \\ ISSN : 1952-420X \\ Éditeur \\ Éditions de l'EHESS
}

Édition imprimée

Date de publication : 1 mars 1996

ISSN : 0248-6016

Référence électronique

Charis Cussins, « Les cycles de la conception : les techniques de normalisation dans un centre de traitement de la stérilité ", Techniques \& Culture [En ligne], 25-26 | 1996, mis en ligne le 28 octobre 2005 consulté le 29 septembre 2022. URL : http://journals.openedition.org/tc/523 ; DOI : https://doi.org/ $10.4000 /$ tc. 523

Ce document a été généré automatiquement le 29 septembre 2022.

Tous droits réservés 
Les cycles de la conception : les techniques de normalisation dans un centre de traitement de la stérilité

Charis Cussins 